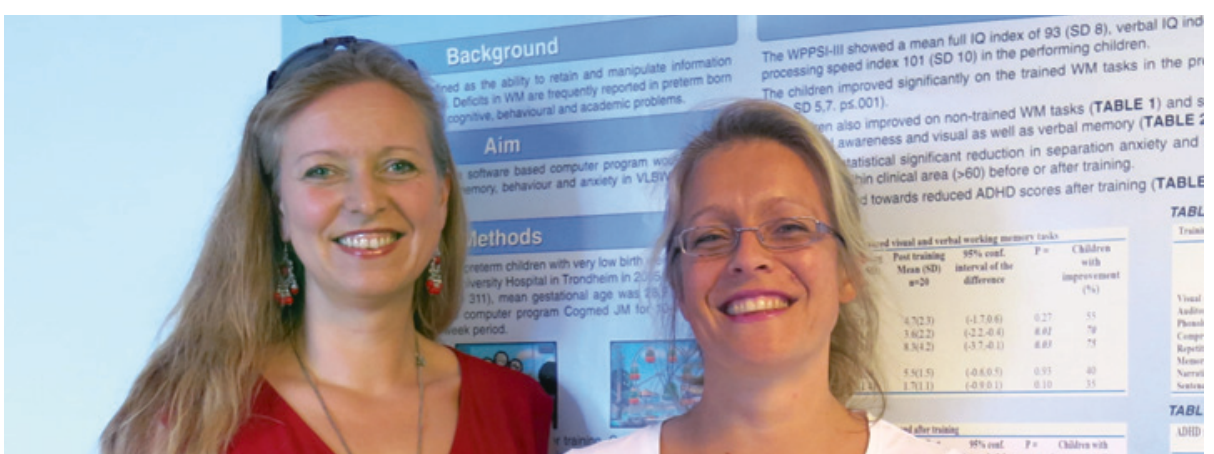

Gro Løhaugen og Kristine Hermansen Grunewaldt forsker på barn som er født prematurt. Foto Eszter Vanky, Norges teknisk-naturvitenskapelige universitet

\title{
Barn født prematurt kan trene opp kognitive funksjoner
}

Førskolebarn som var født prematurt fikk bedre arbeidsminne

etter å ha gjennomført et databasert treningsprogram.

Nevrologiske forstyrrelser ses hyppigere hos barn født prematurt enn hos barn født til termin. Flere studier har vist at premature ofte har nedsatt konsentrasjonsevne, vansker med eksekutive funksjoner og dårlig arbeidsminne. Disse funksjonene er essensielle for læring, planlegging og problemløsning og vil påvirke hvordan barnet mestrer skolegangen og fungerer sosialt. Svikt i disse funksjonene kan derfor få store konsekvenser også i voksen alder og $\mathrm{i}$ arbeidslivet.

Arbeidsminnekapasiteten kan økes gjennom trening. Et databasert treningsprogram, utviklet ved Karolinska Institutet i Stockholm, har vist gode resultater både hos barn med $\mathrm{AD} / \mathrm{HD}$, barn med traumatiske hjerneskader og hos ungdommer som ble født prematurt.

Forskere fra Norges teknisk-naturvitenskapelige universitet har nå undersøkt om databasert arbeidsminnetrening kan ha positiv effekt for prematurt fødte allerede i førskolealder (1). I en prospektiv studie ble 20 barn i alderen 5-6 år som hadde hatt en fødselsvekt på under $1500 \mathrm{~g}$, trent 10-15 minutter daglig fem dager i uken over totalt fem uker. De ble testet med et stort nevropsykologisk testbatteri før og etter treningsperioden, og ved hjelp av et spørreskjema til foreldrene ble det gjort en kartlegging av adaptiv funksjon, angst og symptomer på oppmerksomhetsvansker.

Etter treningsperioden var det signifikant bedring i resultat på arbeidsminnetester. Hos forsøksbarna var det også klar bedring knyttet til auditiv/fonologisk oppmerksomhet og i visuell og verbal hukommelse, noe som trolig representerer en overføringseffekt fra arbeidsminnetreningen til andre kognitive funksjoner. Studien er publisert i det anerkjente pediatriske tidsskriftet Pediatrics.

- Vi konkluderer med at førskolebarn født prematurt med fødselsvekt under $1500 \mathrm{~g}$ har positiv effekt av et databasert treningsprogram, sier Kristine Hermansen Grunewaldt, som er førsteforfatter på artikkelen. - Slik trening kan muligens redusere kognitive problemer som påvirker fremtidig skolegang, men funnene må bekreftes i større studier før en generell anbefaling kan gis.

\section{Langtidsoppfølging av premature} Prosjektet ble gjennomført ved Institutt for laboratoriemedisin, barne- og kvinnesykdommer, Det medisinske fakultet, Norges teknisk-naturvitenskapelige universitet, av en klinisk multidisiplinær forskningsgruppe med særlig interesse for hjerneutvikling og langtidsoppfølging av premature og barn med lav fødselsvekt. Gruppen samarbeider med flere store internasjonale forskningsgrupper, bl.a. i USA (San Diego, Hawaii), Nederland, Sverige og Norge. De har de siste årene gjennomført studier med kognitiv intervensjon og arbeidsminnetrening hos Trondheims-ungdommer som var født prematurt, hos barn med prenatal ruseksponering og hos hivinfiserte voksne på Hawaii.

Den aktuelle studien ble planlagt og ledet av professor Jon Skranes, som har lang erfaring innen langtidsoppfølging av premature og MR-basert forskning på hjernens utvikling. Artikkelens førsteforfatter er barnelege Kristine Hermansen Grunewaldt, som er ph.d.-stipendiat i gruppen. Ph.d. Gro Christine C. Løhaugen, øyelege og ph.d. Dordi Austeng og professor Ann-Mari Brubakk er medforfattere.

\section{Hanne Støre Valeur}

hanne.store.valeur@legeforeningen.no

Tidsskriftet

\section{Litteratur}

1. Grunewaldt KH, Løhaugen GC, Austeng D et al. Working memory training improves cognitive function in VLBW preschoolers. Pediatrics 2013; 131: e747-54.
Ordforklaringer

Arbeidsminne: Evnen til å holde på og bearbeide informasjon over en kort periode. Problemer med arbeidsminnet er knyttet til dårligere kognitiv funksjon og lærevansker, noe som kan ha vedvarende effekt i ungdomstiden og inn i voksen alder og arbeidsliv.

Eksekutiv funksjon: Evnen til problemformulering, problemløsning, planlegging og gjennomføring av oppgaver. Dette er viktige funksjoner, også i det sosiale liv.

Fonologisk oppmerksomhet: Evnen til å skille de enkelte lydene i ordenes lydstruktur. Spiller en sentral rolle innenfor utviklingen av språkferdigheter, som igjen er viktig for å lære å lese og for å utvikle matematiske ferdigheter.

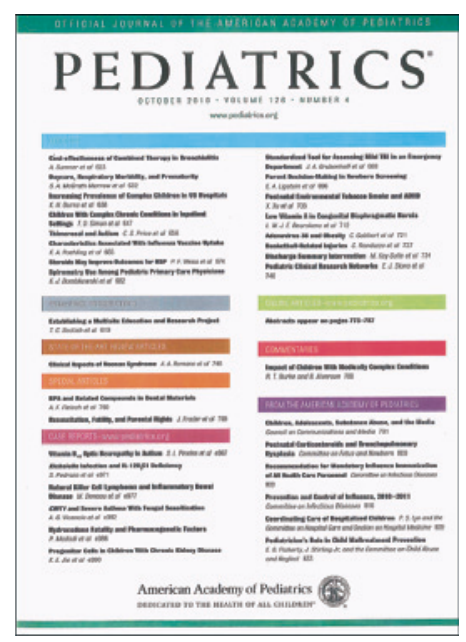

Artikkelen ble publisert i marsutgaven 2013 av tidsskriftet Pediatrics (http://pediatrics. aappublications.org//, som er ett av de høyest rangerte pediatriske tidsskrifter. 